\title{
Sustaining Effective Literacy Practices Over Time in Secondary Schools: School Organisational and Change Issues
}

\author{
Stephen May \\ School of Education, University of Waikato, New Zealand
}

The effective, sustained implementation of literacy across the curriculum in secondary schools is still a relatively rare phenomenon. This is because such an approach to literacy requires secondary schools to undergo extensive and complex processes of school change, involving altering teachers' thinking, attitudes and behaviour in relation to literacy and pedagogy, and establishing and maintaining organisational processes that support teachers' change processes and their impact on student learning. Such changes take time, not least because they often run counter to traditional organisational and pedagogical approaches in secondary schools. Drawing on our research evaluation of the Secondary Schools' Literacy Initiative (SSLI) in New Zealand, this paper examines the medium to long term implications of school change processes for secondary schools undertaking a cross-curricular literacy focus. In so doing, it identifies three key phases that secondary schools may undergo in order to achieve and sustain effective literacy practices over time and suggests that these phases, and their characteristics, may well have wider applicability.

doi: $10.2167 / l e 799.0$

Keywords: literacy, secondary schools, school organisation, school change, whole school, cross-curricular, effective schools, professional development

\section{Introduction}

... we have a considerable body of research on what effective schools and teachers do to promote reading success in the elementary grades. We also possess a great deal of knowledge about successful school reform and the importance of professional development in that process. The missing piece for schools, however, seems to be the procedural knowledge about how to translate this research into school and classroom practices that lead to improved reading performance for their students. (Taylor et al., 2005: 40, 43)

Taylor et al. make this observation in light of their excellent recent analysis of a research-based approach to literacy professional development (PD) in 'high poverty' elementary (primary) schools in the United States. The quote highlights clearly the key challenge that such schools face in implementing literacy across the curriculum effectively - that is, how to operationalise research-attested effective literacy practices in classrooms in order to improve student literacy outcomes (see May, 1997; Wright, in press). 
But what Taylor et al. don't say is equally telling. For example, while much research may have been conducted on elementary or primary schools with respect to reading, there remain demonstrably far fewer research studies on effective literacy practices in secondary or high schools (for some notable exceptions, see Corson, 1999; Knott, 1985; Moje et al., 2000; O'Brien et al., 1995). Part of this may be because there are often far greater organisational and bureaucratic constraints in secondary schools to effecting such changes. Secondary schools are generally larger and more complex organisations than their primary counterparts and are also the least changed of any schooling structure since the advent of mass education, with the industrial management model (and its accompanying bureaucracy) adopted for secondary schools at the time a still-prominent feature (O'Brien et al., 1995). As David Corson observes of this: 'Present-day high schools are usually very large bureaucracies. They are multi-purpose organisations with a chain of command that can be highly diversified and rather weak' (1999: 4). Corson proceeds to comment that there is also often a disjuncture between whole-school literacy policies (such as they are) and the literacy practices of particular subject department domains, which retain considerable autonomy in the secondary school system. Indeed the subject-based nature of secondary schooling can present a major impediment to the successful development of a whole-school approach to literacy in secondary schools. As O'Brien et al. argue, 'the secondary curriculum is based on the assumption that knowledge can be objectified, verified, and disseminated via compartmentalised disciplines' (1995: 448). Consequently, subject area disciplines are not often questioned or deconstructed, particularly those apparently 'high-status' subjects such as mathematics and science, while their often near-hermetic boundaries militate directly against cross-disciplinary initiatives such as literacy across the curriculum.

Taylor et al.'s comments also reflect a wider preoccupation in recent years with the acquisition of reading in elementary schooling, narrowly defined and assessed, and often at the expense of more holistic, longer-term, and crosscurricular conceptions of literacy pedagogy and practice (see Corson, 1999; Janks, in press; Lankshear, 1997; see also Smyth, this issue). This preoccupation is reflected methodologically in a preponderance of experimentalist studies, focussing primarily on the cognitive processes associated with reading (and writing). Too little attention is given to the sociocultural context of literacy that is, 'the view that meaning is situated in particular events and interactional contexts in which teachers and students construct the culture of their [secondary] classroom, which in turn defines and constrains how they view literacy and learning' (O’Brien et al., 1995: 450; see also Smyth, this issue).

And finally, while obviously implicit in Taylor et al.'s comment, there is no overt inclusion of teachers as active agents of pedagogical change. And yet, the degree to which effective literacy practices in both primary and secondary schools can be established, let alone sustained, is almost wholly dependent on the degree to which teachers take ownership of those practices, individually and collectively - developing, in so doing, an effective literacy 'community of practice' (see Wright, this issue) in those schools. As O'Brien et al. again perceptively observe, to understand why efforts to develop effective literacy practices in secondary schools succeed or fail, 'one must understand the compatibility or incompatibility between the intentions and values of [key] change agents on 
the one hand, and the intentions, values, and work of persons in schools on the other' (1995: 452). In other words, without wide teacher 'buy-in', literacy across the curriculum initiatives are bound to fail.

Given these various lacunae, it seems timely to focus on the medium- to longterm implications for secondary schools of implementing a cross-curricular approach to literacy across the school as a whole, as well as within particular subject departments. In so doing, I will draw on the wider school change literature, where relevant, but will focus, in particular, on the research findings arising out of the SSLI project with respect to these questions. These include the identification of three key phases in the development of an effective approach to literacy over time in secondary schools.

The initial phase involves a school raising the awareness of staff about the need for effective literacy practices, what these might comprise, what the current situation in the school is regarding students' existing literacy-related skills and abilities, and negotiating the role of teachers in supporting and learning more about them. This is where a community of practice centred on literacy begins to develop. This initial phase may be a long one for some schools, often spanning a number of years, depending on the level of staff 'readiness' to address these issues. Peeling away existing beliefs and expectations, and customary teaching practices, can take time. In this phase, collecting, analysing and interpreting assessment data about students' skills and abilities in order to alert teachers about what they may need to help students with, can be revelatory, but does take planning, resources and significant preparation. While this is a necessary stage for schools to undertake, and while much attitudinal shift among teachers may occur, it is unlikely that extensive changes to teacher practice will be apparent at this point, or that substantive changes to student outcomes will result.

The second phase presupposes the successful negotiation of the initial phase, and the subsequent development of school-wide strategies that are beginning to change literacy practices among individual teachers and to provide the basis for changing/improving student literacy outcomes. Schools, at this stage, have undertaken sufficient prior PD to be 'ready' to instantiate effective literacy strategies in teaching and learning practices across the school, and in ways that begin to impact positively on student outcomes. The second phase is, thus, where schools gain some literacy traction; they experiment with research-attested literacy strategies and knowledge, and teachers develop, along with this new knowledge, their self-reflective skills and a more focussed literacy community of practice. Schools are likely to have their goals and systems in place, including effective summative and formative assessment practices, so that the development of teachers' knowledge and literacy practices can occur within a coherent framework and be based on the identified literacy needs of their students.

The final, crucial third phase has to do with sustaining changed literacy (and wider learning and teaching) practices over time, particularly in light of changes to staff and other PD emphases within schools. It is the key phase within which schools and teachers are confident enough to adapt, share and discuss literacy and learning across subjects and curriculum boundaries. It is also the phase where teachers within subject and curriculum boundaries are actively adapting their own teaching and learning approaches in order to scaffold more effectively the literacy demands of their subjects and the associated texts and textual 
practices they use. How the school collects and examines student literacy data to inform its teaching and learning practices will also be further developed in this phase, incorporating not just summative and formative assessment practices, as in the previous phases, but also diagnostic- and disciplinary-related assessments. When this level of disciplinary-based analysis and implementation occurs across the school, in tandem with a cross-curricular understanding of literacy, effective literacy practices are more likely to be sustained over time.

These three identified phases necessarily suggest that schools will have to undergo a clear developmental process in relation to implementing literacy across the curriculum. In this sense, they can be seen as broadly comparable to Guskey's (2000) key stages of change for teachers in effective PD. ${ }^{1}$ However, as with Guskey's analysis, the three phases are not meant to be seen as discrete there will inevitably be overlap between them and movement back and forward by schools and teachers in relation to them, depending on the timing, nature and context of the change processes involved. The key issue, as Taylor et al. observe, is to 'follow a change process that helps solve problems and moves the agenda forward' (2005: 44).

\section{Effective Schools and Literacy Professional Development}

The research literature on school effectiveness and school change processes has burgeoned in recent years (see, for example, Fink, 2000, 2005; Fullan, 1999; Fullan \& Hargreaves, 1996; Hargreaves \& Fink, 2006; Hawley, 2002; Stoll et al., 2003). While much of this literature is open to the criticism of promoting a superficial managerialism, not always appropriate for education (see Thrupp \& Willmott, 2003 for an extended critique along these lines), it nonetheless provides a useful point of reference in discussions of effective literacy practices in secondary schools. For example, both the school effectiveness and school improvement literature stress the importance of proactive, inclusive leadership, staff openness and collaboration, ongoing PD, critical reflection on teaching, learning and related assessment practices including effective analysis of student achievement data, and open, productive and reciprocal school and community partnerships. As Taylor et al. (2005: 44) summarise:

Schools that have had successful improvement efforts typically operate as strong professional learning communities, with teachers systematically studying student assessment data, using the data to modify their instructions, and working with colleagues to refine their teaching practices... Reflective dialogue, deprivatization of practice, and collaborative efforts all enhance shared understandings and strengthen relationships within a school.

No one would likely disagree with this, but bringing it about in secondary schools is far easier said than done. Findings from the SSLI research evaluation, for example, reveal that a significant strength of this particular literacy intervention was its combination of facilitation of, and support in, literacy by designated external, regionally based literacy facilitators (RFs), alongside a specific focus on helping schools establish their own literacy communities of practice, particularly via the formal establishment of a 'literacy leader' (LL) in the school 
(see Wright, this issue, for an extended discussion). Even so, the literacy PD intervention itself was only for one year, and our findings highlight that it may take between 3-5 years, at a minimum, to embed a professional literacy learning community within a school to the point where it begins to have a significant impact on student literacy outcomes. In other words, while the SSLI intervention was clearly a significant one, it nonetheless could not in itself achieve immediate change in the short term, or sustainable change over the longer term, without further processes and systems being established by schools, along with ongoing, targeted and relevant PD support. Taylor et al. (2005: 65; see also Poulson \& Avramidis, 2003) make a similar observation in relation to the primary schools that their study focussed upon:

Effective school improvement is a complex, multiyear process ... and we must be willing to stay the course in these schools for at least five or six years in order to fully understand the nature of the change

The individual school context also becomes particularly important here, highlighting the significance of tailoring PD in literacy appropriately to the particular circumstances of individual schools. For example, the extent to which the SSLI intervention had an impact in the given year a school was involved with it, and what kinds of impact it had, depended almost entirely on the particular school's pre-existing PD history in relation to literacy - what we termed the level of 'school readiness'.

In the SSLI research evaluation, we found that schools were at widely variant stages of 'readiness' in relation to the SSLI PD intervention, requiring regional literacy facilitators to work in often widely different ways with individual schools, depending on their circumstances. This is not problematic in itself - indeed, it should be expected - but it does highlight the importance of avoiding a prescriptive, recipe approach to literacy-related PD and/or presuming that PD interaction should always stay the same, even within individual schools. The latter also highlights the significance of PD cycles and the need to adapt PD in light of those cycles and the emerging literacy community of practice in schools. Such recognition will inevitably impact on the level, focus and frequency of literacy PD interventions within a particular school, as well as across schools (McClesky \& Waldron, 2002). Another critical feature here is to be able to explore how schools might progress through various cycles or stages, from establishing to consolidating and, eventually, to sustaining changed literacy practices over time. It is to this phasal development, and its characteristics, that I now want to turn.

\section{Key Phases in Secondary Schools' Literacy Development}

Over the course of the SSLI research evaluation, it became apparent that the 60 schools involved over the three years (20 schools per year), fitted broadly into one of three categories of school readiness. We suggest that these phases may have wider, more generalisable, application. The three phases of school readiness, which will be described in detail as follows, are analysed in relation to a number of key features. These are: 
- the particular literacy focus of the school;

- the key change agents involved and their associated roles;

- the nature of the PD undertaken;

- the literacy resources drawn upon;

- the analysis and use of literacy data;

- the impact on student outcomes.

These features are also analysed in relation to three key domains:

- internal school processes;

- the interaction of these school processes with outside PD facilitation;

- the PD facilitation process itself.

\section{Phase 1: Establishing effective literacy practices}

The bulk of the secondary schools in the SSLI intervention, as we suspect more generally, were to be found in this initial phase - at or near the beginning of rethinking literacy practices in their school. This initial phase is often precipitated by a concern with a particular literacy issue (e.g. reading for comprehension; vocabulary acquisition), and/or a particular group of students who may be faring less well comparatively to their peers. Consequently, initial perceptions of literacy may well be narrowly defined, and can also be constructed unhelpfully in 'remedial' and/or deficit terms, although this does not (nor should it) have to be the case. Nonetheless, focussing on a particular 'language problem' (Corson, 1999) may provide a useful basis for further action on literacy within a school. It can be a catalyst for raising the awareness of staff about the need for effective literacy practices in the first instance and what these might comprise. From this, a focus can be developed on extending teacher knowledge about effective literacy practices and, if necessary, changing often long-held teacher attitudes about literacy, and associated customary teaching practices. As Corson comments, 'teachers often vary greatly in their readiness to acknowledge the central role of language in learning.... so, just changing some of these teacher attitudes, or reconciling them with one another, is often the first [and, I would add, most significant] challenge for a [school] language policy to address' (1999: 89-90).

As we have already seen, existing attitudes to literacy in secondary schools pose particular challenges here, not least because of the compartmentalised, often hermetic thinking that different curriculum subjects still impose on school organisation. As Corson proceeds to observe, this raises several key questions that need to be addressed in this initial phase:

- How can teachers come to see that language development in secondary schools is everyone's responsibility?

- How can subject teachers move beyond the transmissionist delivery of subject content to incorporate more effective teaching and learning processes?

- How can assessments and examinations be employed in ways that allow more fusion of the language and learning process?

It is in addressing these questions that secondary teachers must learn that the responsibility for supporting students' literacy does not lie elsewhere - with 
parents, primary schools or the English department - but with individual subject teachers, working in their curriculum areas. It is only when widespread ownership of literacy occurs across the teaching staff in this way that schools will likely be able to move onto the next stage - and many schools, unable to manage this, simply do not get beyond this point.

One key way to make progress in this regard is for teachers to be made specifically aware of the literacy-related skills and needs of their students, alongside any related literacy trends or norms in relation to the wider population. This requires, in turn, the systematic collecting, analysing and interpreting of data about students' literacy skills and abilities as a basis for identifying how teachers may then best help students. Such an approach accords with Corson's (1999) advocacy of school-based 'fact gathering' and the wider advocacy of using student literacy data as an initial basis for literacy development in schools (cf. O'Brien et al., 1995; Poulson \& Avramidis, 2003; Taylor et al., 2005). Systematic and informed evidence-gathering of this kind can be revelatory, particularly in being able to highlight students with the greatest literacy needs, but does take planning, resources and time to prepare. More crucially, it also requires a strategy for making the subsequent data available to teachers in ways that can usefully inform their teaching. At this initial phase it was evident that the majority of schools in the SSLI were extremely diligent in assessing their students' literacy via established summative literacy measures, with a designated teacher most often specifically responsible for data collection. However, schools were much less able to explain why particular summative measures were chosen and used - it was, more often than not, the result of historical or customary practice. Nor were they able and/or inclined to use these data effectively (if at all) for subsequent formative and diagnostic purposes (see Whitehead, this issue).

In this initial phase, the role of literacy PD is likely to be externally driven and at the whole-school level. External/regional literacy facilitators (RFs) aim to introduce some of the key cross-curricular literacy approaches, and related research, to staff at relevant school PD sessions. RFs may also play a crucial role in assessing the school's existing literacy achievement data, using the data analysis as an evidence basis for future action. RFs also play an important role in this initial phase in building the literacy knowledge of key change agents within the school, particularly the designated literacy leader (LL). In fact, the ability of the LL to begin to build internal school capacity in literacy, alongside the external facilitation, is a key factor in contributing to the success (or otherwise) of the cross-curricular literacy initiative over time. An LL must not only have sufficient literacy content knowledge himself/herself but must also be able to facilitate and scaffold staff in their own processes of change (Corson, 1999). This requires that they be a 'strong and respected teacher leader who [is] persistent in helping teachers examine the data linking students' growth to classroom practices' (Taylor et al., 2005: 65) and who is also able to model literacy approaches appropriately. Fulfilling this key mentoring role also requires clearly and consistently articulated support from the principal and senior management within a school, as well as, if possible, specific time, management and resource support. Indeed, schools in the SSLI who made the most progress were, not surprisingly, perhaps, those who had a highly regarded LL (or, in some case, a number of LLs) 
with both designated time and management allocations for the role. If these LLs were also supported by a dedicated team of teachers - a literacy committee, in effect - this further enhanced their effectiveness (cf. Corson, 1999; Taylor et al., 2005).

In summary, this initial phase provides the essential foundations for a secondary school to begin to address cross-curricular literacy issues effectively and to begin to work towards changing teacher attitudes in relation to literacy teaching and learning. However, it takes time - often a number of years - and while much attitudinal shift may occur over that period, it is unlikely that extensive changes to teacher practice, or substantive changes to student outcomes, will result. Nonetheless, if this stage is successful, staff will have experienced - often for the first time - new cross-curricular approaches to literacy teaching and learning and have begun to realise, and focus upon, the importance of those approaches to their own subject areas. A diagrammatic view of the issues that attend this phase of literacy development, drawn from the SSLI study, can be seen in Table 1.

Table 1 Phase 1: Establishing effective literacy practices

\begin{tabular}{|c|c|c|c|}
\hline & Within the school & Across the school & Within facilitation \\
\hline $\begin{array}{l}\text { Literacy } \\
\text { focus }\end{array}$ & $\begin{array}{l}\text { Identification and } \\
\text { focus on areas of } \\
\text { greatest literacy } \\
\text { need; often } \\
\text { associated with } \\
\text { students at most } \\
\text { risk. }\end{array}$ & $\begin{array}{l}\text { Examination of } \\
\text { existing patterns of } \\
\text { literacy achievement } \\
\text { across the school. }\end{array}$ & $\begin{array}{l}\text { Knowledge of } \\
\text { school's literacy } \\
\text { achievement } \\
\text { patterns in relation } \\
\text { to national patterns. }\end{array}$ \\
\hline Key people & $\begin{array}{l}\text { Principal } \\
\text { Literacy Leader (LL) } \\
\text { Data collection/ } \\
\text { analysis person }\end{array}$ & $\begin{array}{l}\text { External Literacy } \\
\text { Facilitator (RF) } \\
\text { works with } \\
\text { principal, LL and } \\
\text { data person to } \\
\text { develop school plan } \\
\text { and approach. }\end{array}$ & $\begin{array}{l}\text { Content knowledge } \\
\text { about literacy } \\
\text { (theory). } \\
\text { Delivery (literacy } \\
\text { practices). } \\
\text { Knowledge of } \\
\text { change processes. }\end{array}$ \\
\hline Roles & $\begin{array}{l}\text { Principal initiates } \\
\text { literacy focus - e.g. } \\
\text { appoints LL, creates } \\
\text { literacy budget, sets } \\
\text { strategic goals. } \\
\text { LL and Senior } \\
\text { Management Team } \\
\text { (SMT) support } \\
\text { initiative; instigate } \\
\text { work with RF. } \\
\text { RF scopes school's } \\
\text { current situation and } \\
\text { literacy readiness } \\
\text { status. }\end{array}$ & $\begin{array}{l}\text { Structural aspects } \\
\text { considered. } \\
\text { RF may take lead } \\
\text { role in guiding } \\
\text { school on how to } \\
\text { raise awareness of } \\
\text { literacy and its role } \\
\text { in supporting } \\
\text { learning and } \\
\text { academic success. }\end{array}$ & $\begin{array}{l}\text { Focus on facilitating } \\
\text { LL's development } \\
\text { and capacity. } \\
\text { Focus on engaging } \\
\text { and being a catalyst } \\
\text { for team of literacy } \\
\text { volunteers who form } \\
\text { core of community } \\
\text { of practice. } \\
\text { Initiating risk-taking } \\
\text { by staff to learn } \\
\text { about literacy and } \\
\text { trial strategies. }\end{array}$ \\
\hline
\end{tabular}


Table 1 (cont.)

\begin{tabular}{|c|c|c|c|}
\hline & Within the school & Across the school & Within facilitation \\
\hline$P D$ & $\begin{array}{l}\text { Whole-school } \\
\text { awareness-raising } \\
\text { workshops. }\end{array}$ & $\begin{array}{l}\text { Intensive work with } \\
\text { LL to develop their } \\
\text { leadership within } \\
\text { the literacy team. } \\
\text { Some whole-school } \\
\text { PD to raise } \\
\text { awareness about } \\
\text { literacy and the } \\
\text { potential } \\
\text { implications for } \\
\text { teachers. }\end{array}$ & $\begin{array}{l}\text { Demonstration of } \\
\text { PD processes and } \\
\text { literacy content } \\
\text { (theory and } \\
\text { practices). }\end{array}$ \\
\hline Resources & $\begin{array}{l}\text { Time, money, } \\
\text { structures put in } \\
\text { place to make } \\
\text { literacy a key PD } \\
\text { initiative. }\end{array}$ & $\begin{array}{l}\text { Opportunities for } \\
\text { working with } \\
\text { specific literacy } \\
\text { resources. } \\
\text { Notions of 'literacy' } \\
\text { explored. }\end{array}$ & $\begin{array}{l}\text { Working with } \\
\text { literacy resources } \\
\text { and trialling } \\
\text { strategies in } \\
\text { individual lessons. }\end{array}$ \\
\hline Data & $\begin{array}{l}\text { Reviewing types of } \\
\text { assessments used. } \\
\text { Reviewing the use of } \\
\text { data from such } \\
\text { assessments. } \\
\text { Developing } \\
\text { summative analyses } \\
\text { from assessments } \\
\text { employed. } \\
\text { Establishing } \\
\text { evidence basis and } \\
\text { types of assessments } \\
\text { to be used in future. }\end{array}$ & $\begin{array}{l}\text { Advising schools on } \\
\text { appropriate } \\
\text { assessments and } \\
\text { assessment } \\
\text { procedures. }\end{array}$ & $\begin{array}{l}\text { Examining existing } \\
\text { data - what is the } \\
\text { current situation in } \\
\text { the school? }\end{array}$ \\
\hline Outcomes & $\begin{array}{l}\text { Awareness raised; } \\
\text { most teachers } \\
\text { understand their } \\
\text { role as teachers } \\
\text { (blame avoided - } \\
\text { e.g. primary schools, } \\
\text { English teachers; } \\
\text { deficit thinking in } \\
\text { relation to students } \\
\text { is challenged). }\end{array}$ & $\begin{array}{l}\text { Literacy volunteers } \\
\text { become a team, } \\
\text { sharing and trialling } \\
\text { literacy strategies. } \\
\text { Staff talk shifts more } \\
\text { to a focus on } \\
\text { pedagogy; } \\
\text { community of } \\
\text { practice takes shape. } \\
\text { Literacy team } \\
\text { members comment } \\
\text { on student } \\
\text { engagement with } \\
\text { literacy tasks. }\end{array}$ & $\begin{array}{l}\text { Literacy team learns } \\
\text { about what literacy } \\
\text { might mean for } \\
\text { them. } \\
\text { Team members trial } \\
\text { and share strategies } \\
\text { with each other. } \\
\text { Other staff are } \\
\text { exposed to the } \\
\text { team's trials and } \\
\text { their evaluations } \\
\text { informally. } \\
\text { Begin changing } \\
\text { lessons and units at } \\
\text { junior level. }\end{array}$ \\
\hline
\end{tabular}




\section{Phase 2: Consolidating effective literacy practices}

There were a number of schools in the SSLI project that could be said to have reached this second phase. The second phase sees a shift from changed attitudes to literacy among staff to the beginnings of changed literacy practices by staff in and across their classrooms. Literacy, by now, is often conceived in broader, less deficit terms - with the literacy needs of all students, not just those most 'at risk', becoming a school-wide focus. Such conceptions of literacy also acknowledge and address the specifics of academic language, language registers and their contextual situatedness, as well as moving beyond default monolingual positions to begin to include second language learning and teaching issues in positive and constructive ways (see Corson, 1999; May, 1994, 1997).

This second phase is, thus, where schools begin to experiment with literacy strategies and knowledge, and teachers develop, along with this new knowledge, their self-reflective skills and a more focussed literacy community of practice. It is in this phase that schools often benefit most from the support of an external/regional literacy facilitator (RF), who can work with targeted staff and broaden the theoretical and practical knowledge of literacy, guiding staff to trial strategies in their staffroom, departments and classrooms. This may be facilitated by a snowball approach - trialling strategies with selected staff across the school who then act as models and mentors to their departmental colleagues.

Schools are likely to have their goals and systems in place so that the development of teachers' knowledge and literacy practices can occur within a coherent framework. These schools often begin to look beyond literacy as a focus per se, examining its relationship to thinking and learning. This accords with Alvermann's (2002) advocacy of the necessity of linking critical thinking opportunities to literacy instruction and learning. The schools' literacy communities of practice are also well developed, while staffroom talk is usually centred on learning issues. Shifts in students' engagement in learning also become a feature of conversation. These characteristics - where theorised communities of practice develop and learning is emphasised and widely discussed - are key features of schools that engage (more) successfully in PD literacy interventions (cf. Guskey, 2000; O’Brien et al., 1995; Poulson \& Avramidis, 2003; Taylor et al., 2005).

Staff should also be beginning to use literacy assessments more explicitly as a basis for guiding pedagogy and practice, moving from summative analyses to more formative and diagnostic uses in the classroom that can also, then, be used as a basis for deliberate acts of teaching (Alvermann, 2002) ${ }^{2}$. Here, the support of the RF is once again crucial, especially in scaffolding processes by which individual classroom teachers can use student outcome data to directly inform teaching and learning practices in their individual classrooms (see also Whitehead, this issue). As a result, improved student literacy outcomes should begin to become noticeable within classrooms and across the school as a whole, particularly with respect (but not limited) to those students deemed to be most 'at risk'. The characteristics of this phase are summarised in Table 2. 
Table 2 Phase 2: Consolidation of effective literacy practices

\begin{tabular}{|c|c|c|c|}
\hline & Within the school & Across the school & Within facilitation \\
\hline $\begin{array}{l}\text { Literacy } \\
\text { focus }\end{array}$ & \multicolumn{2}{|c|}{$\begin{array}{l}\text { Broader focus on a range of literacy needs, and } \\
\text { students, across the school, not just those most } \\
\text { 'at risk'. }\end{array}$} & $\begin{array}{l}\text { Focus on } \\
\text { approaches, } \\
\text { emphases } \\
\text { appropriate to the } \\
\text { differing literacy } \\
\text { needs of students } \\
\text { across the school. }\end{array}$ \\
\hline $\begin{array}{l}\text { Key } \\
\text { people }\end{array}$ & \multicolumn{2}{|c|}{$\begin{array}{l}\text { Literacy Leader (LL) \& team } \\
\text { External Literacy Facilitator (RF) and Senior } \\
\text { Management Team (SMT) support. }\end{array}$} & $\begin{array}{l}\text { PD processes; } \\
\text { change leadership; } \\
\text { literacy content. }\end{array}$ \\
\hline Roles & $\begin{array}{l}\text { Facilitation } \\
\text { Mentoring } \\
\text { Modelling } \\
\text { Sharing }\end{array}$ & \multicolumn{2}{|c|}{$\begin{array}{l}\text { One-to-one advice, guidance and support. } \\
\text { Small/targeted groups provided with specific } \\
\text { literacy knowledge, content, strategies and skills }\end{array}$} \\
\hline$P D$ & $\begin{array}{l}\text { Teams learn about } \\
\text { and trial strategies in } \\
\text { their classrooms. }\end{array}$ & $\begin{array}{l}\text { RF conducts whole-school } \\
\text { seminars. } \\
\text { LL and literacy team } \\
\text { demonstrate use of } \\
\text { specific strategies within } \\
\text { their classrooms. } \\
\text { Departmental goals and } \\
\text { literacy foci identified. }\end{array}$ & $\begin{array}{l}\text { Subject-specific } \\
\text { examples } \\
\text { provided. } \\
\text { Subject-specific } \\
\text { facilitation occurs. } \\
\text { Wide view of } \\
\text { literacy - } \\
\text { acknowledgement } \\
\text { of L2 students and } \\
\text { their needs. }\end{array}$ \\
\hline Resources & $\begin{array}{l}\text { Appropriate literacy } \\
\text { resources, both } \\
\text { externally and } \\
\text { internally generated. } \\
\text { Staff share ideas and } \\
\text { resources formally } \\
\text { and informally. }\end{array}$ & \multicolumn{2}{|c|}{$\begin{array}{l}\text { Selection of specific, classroom-based and } \\
\text { content-oriented strategies. } \\
\text { Adaptation, rather than adoption of ideas. } \\
\text { Literacy community of practice widens to in- } \\
\text { clude others beyond literacy team. }\end{array}$} \\
\hline Data & $\begin{array}{l}\text { Purposes for } \\
\text { analysis clarified. } \\
\text { Specific assessments } \\
\text { chosen for school's } \\
\text { current/future } \\
\text { needs rather than on } \\
\text { the basis of historical } \\
\text { practice. } \\
\text { Complementing } \\
\text { summative analysis } \\
\text { with formative } \\
\text { assessment and } \\
\text { analysis. }\end{array}$ & \multicolumn{2}{|c|}{$\begin{array}{l}\text { Teachers begin to design diagnostic and nor- } \\
\text { mative assessments that reflect the pedagogical } \\
\text { and literacy practices implemented in their class- } \\
\text { rooms. } \\
\text { Classroom-based practices designed to suit con- } \\
\text { tent, skills, knowledge and strategies } \\
\text { Teachers developing and honing reflective prac- } \\
\text { tices. }\end{array}$} \\
\hline
\end{tabular}


Table 2 (contd)

\begin{tabular}{|l|l|l|l|}
\hline Within the school & Across the school & Within facilitation \\
\hline Outcomes & $\begin{array}{l}\text { Data used to inform } \\
\text { pedagogy. }\end{array}$ & $\begin{array}{l}\text { Teachers share classroom practices and experi- } \\
\text { ments with literacy strategies. } \\
\text { Community of practice gains momentum. } \\
\text { Staffroom discourse centres on learning. } \\
\text { Assessment practices reviewed and revised. } \\
\text { Units revised to better reflect effective literacy, } \\
\text { assessment and pedagogical practices. } \\
\text { Specific ability to recognise student needs. } \\
\text { Differentiated texts and learning more deliber- } \\
\text { ately selected. } \\
\text { Staff comment on changed student attitudes to } \\
\text { learning. } \\
\text { Students begin to transfer literacy learning } \\
\text { strategies from subject to subject. } \\
\text { Teachers employ more deliberate acts of teach- } \\
\text { ing in their classrooms. } \\
\text { Senior classes experience literacy; senior pro- } \\
\text { grammes begin to reflect effective learning; aca- } \\
\text { demic language specifically addressed. } \\
\text { Changes to student literacy achievement pat- } \\
\text { terns beginning to occur, particularly, for those } \\
\text { most 'at risk'. }\end{array}$ \\
\hline
\end{tabular}

\section{Phase 3: Sustaining effective literacy practices}

Very few schools in the SSLI research evaluation could be said to have reached this third phase, where effective literacy practices are consistently sustained over time across the school and within subject departments. Adjudging from the available international research literature on secondary literacy contexts, this is also likely to be the case elsewhere. As such, the descriptions that follow are necessarily somewhat speculative, extrapolating from trends apparent from those schools that were on the cusp of moving from Phase 2 into this subsequent phase in the SSLI project.

At Phase 3, it is expected that schools will have not only a broader but also a more critical conception of literacy - incorporating the much wider range of textual modalities and the related multiliteracies required to engage with them effectively (see, for example, Cope \& Kalantzis, 1999; Education Queensland, 2000; Knobel \& Lankshear, 2007; Lankshear \& Knobel, 2003; Street \& Hornberger, in press). As Luke et al. in Queensland, Australia, argue, this necessitates an approach to literacy teaching and learning that 'is about pedagogy, about focussed instruction, about scaffolding and goal-directed activities with a range of texts and media' (Education Queensland, 2000: 10). The consequence of this more socially critical view of literacy and learning is a greater sensitivity to the teaching and learning context and, especially, the relationships between teachers and learners. As Corson summarises it: '[i]n practice, this means moving the 
emphasis away from artificial textbooks and towards "real" materials integrating and drawn from these multiple literacies' (1999: 165). This should include, Corson argues, materials and resources in the various home languages and/or language varieties of students, specifically bridging first and second language learning contexts.

Such a conception also foregrounds how, as Alvermann argues, 'adolescents who appear most "at risk" of failure in the academic literacy arena are sometimes the most adept at (and interested in) understanding how media texts work, and in particular, how meaning gets produced and consumed' (2002: 200). This, in turn, requires that teachers' professional focus continues to move from the use of teaching (teacher) activities / strategies - still dominant in many approaches to literacy instruction - towards learning (learner) strategies. The most likely means by which the sustainability of literacy across the curriculum can be achieved is by creating independent and strategic learners. Shifting responsibility for learning from teachers to the students, through a guided, coconstructive and scaffolded method, facilitates this process. At the same time, teachers need a scaffolding process of developmental learning for themselves, through a community of practice centred on literacy (see Wright, this issue), which continues to extend/expand their own understandings of literacy and learning (not to mention related processes of organisational change). Busher contends that such 'learning communities [are] sites where people expand their capacities to work in new and creative ways through working together' (2005: 461). It is through the work of internal school change agents, such as literacy leaders (LLs), and ongoing external facilitation and support that literacyoriented capacities can expand and eventually become self-sustaining. One obvious way in which this might occur is via specific action research based studies generated from within the school as a result of such practices, thus 'creating sustained opportunities for teachers to make practical knowledge explicit to themselves and others; to make connections between practical and theoretical knowledge; and to engage in activities beyond their own school' (Poulson \& Avramidis, 2003: 557; cf. Taylor et al., 2005). Another is to continue to induct new staff into the existing literacy understandings and practices reached by the school.

These potential developments suggest that the nature of both internal and external literacy facilitation will also necessarily change over time. Indeed, it might be expected at this stage that the focus on capacity building - having achieved breadth, or coverage across the school in terms of teacher buy-in - might now focus more on establishing disciplinary depth. The latter might involve working with disciplinary- or subject-based teams to instantiate effective literacy teaching and learning practices in those areas, both in relation to the texts and related textual practices that are regularly used, and with respect to the wider aim, discussed earlier, of creating independent learners in these contexts. This might also necessitate a change in role for key change agents - LLs, for example, might take on more of a mentoring/modelling role, while Heads of Department or Faculty become much more central to facilitating (or resisting) the adoption of effective literacy practices within their discipline(s).

Finally, how the school collects and examines student literacy data to inform its teaching and learning practices will likely be further developed in this phase, incorporating not only summative and formative assessment practices, as in 
the previous phases, but also diagnostic, disciplinary-related assessments that allow for an ecologically valid approach to literacy teaching and learning in specific classroom contexts (see Whitehead, this issue for further discussion). These various characteristics are summarised in Table 3.

Table 3 Phase 3: Sustaining effective literacy practices

\begin{tabular}{|c|c|c|c|}
\hline & Within the school & Across the school & Within \\
\hline & \multicolumn{3}{|c|}{$\begin{array}{l}\text { Focus not only on different student literacy needs, but also dif- } \\
\text { ferent types of literacy; multimodal; multiliteracies; linking 1st } \\
\text { and 2nd language needs. }\end{array}$} \\
\hline Key people & $\begin{array}{l}\text { LL } \\
\text { Principal (structural } \\
\text { role). }\end{array}$ & $\begin{array}{l}\text { Literacy team - } \\
\text { department/subject } \\
\text { focus. }\end{array}$ & $\begin{array}{l}\text { Subject-specific staff } \\
\text { HODs/HOFs }\end{array}$ \\
\hline Roles & \multicolumn{3}{|c|}{$\begin{array}{l}\text { - One-to-one or small subject-specific group facilitation, with } \\
\text { - } \text { - Resourticular discipline/subject focus; } \\
\text { - } \text { Networking - matching expertise to need; } \\
\text { - Mentor role and developing other in-school literacy 'experts'; } \\
\text { - Teambuilding; } \\
\text { - Facilitation; } \\
\text { - Change processes understood and used effectively to } \\
\text { support literacy/pedagogy change; } \\
\text { - Leadership development; } \\
\text { - LL role evolves into leading learning rather than just } \\
\text { literacy; 'lead teacher' role; } \\
\text { - Principal advocates for LL funding and time allowance; } \\
\text { requires departments/faculties to account for literacy within } \\
\text { subject jurisdictions; school language/literacy policy } \\
\text { implemented and } \\
\text { - HODs/HOFs and/or key subject teachers lead } \\
\text { subject/discipline-specific literacy practices. }\end{array}$} \\
\hline$P D$ & \multicolumn{3}{|c|}{$\begin{array}{l}\text { - Subject-specific; } \\
\text { - Internally generated and based on local data; } \\
\text { - Externally assessed language/literacy requirements } \\
\text { understood across subjects; } \\
\text { - Literacy induction of new staff is part of PD programme; } \\
\text { - Teachers develop own qualifications through further } \\
\text { university study; } \\
\text { - Succession-planning/mentoring; } \\
\text { - Literacy community of practice now includes most staff, via } \\
\text { subject/discipline-specific teams and } \\
\text { - Wider issues of pedagogy and education debated. }\end{array}$} \\
\hline
\end{tabular}


Table 3 (cont.)

\begin{tabular}{|c|c|c|c|}
\hline & Within & Across the school & $n$ \\
\hline Resources & \multicolumn{3}{|c|}{$\begin{array}{l}\text { - Staff generate their own literacy resources in relation to their } \\
\text { teaching areas; } \\
\text { - Adapt and refine existing strategies and } \\
\text { - Wide sharing (e.g. through templates/samples on shared } \\
\text { server space; staffroom discussion). }\end{array}$} \\
\hline Data & \multicolumn{3}{|c|}{$\begin{array}{l}\text { - Subject-specific and classroom-based data analysed and } \\
\text { used purposefully to support learning in diagnostic and } \\
\text { reflective ways; } \\
\text { - Teachers have practical applications for information; } \\
\text { - Tracking/monitoring of student literacy achievement from } \\
\text { year to year. }\end{array}$} \\
\hline Outcomes & $\begin{array}{l}\text { - Teachers and scl } \\
\text { achievement an } \\
\text { - Stronger and mo } \\
\text { pedagogy and a } \\
\text { - Community of } \\
\text { skills in data anc } \\
\text { - Quality of inforr } \\
\text { - Theoretical knor } \\
\text { and competence } \\
\text { - Staffroom and d } \\
\text { on learning issu } \\
\text { - Classrooms becc } \\
\text { teacher-oriented } \\
\text { - Students' learni } \\
\text { - Whole-year leve } \\
\text { literacy foci, incl } \\
\text { diagnosis and ac } \\
\text { - Concerted atten } \\
\text { - Students in relat } \\
\text { - Focus broadene } \\
\text { backgrounds ap } \\
\text { learning; } \\
\text { achool becomes } \\
\text { educational issu } \\
\text { Significant chan } \\
\text { - }\end{array}$ & $\begin{array}{l}\text { have better inform } \\
\text { isting skills; } \\
\text { authentic relationsh } \\
\text { sment; } \\
\text { tice widens to inclu } \\
\text { is and application; } \\
\text { ion improves; } \\
\text { gge of literacy increa } \\
\text { rtmental discourses } \\
\text { more student-orien } \\
\text { engagement and bel } \\
\text { ogrammes are revis } \\
\text { ng assessment pract } \\
\text { n; } \\
\text { given to academic } \\
\text { to specific subject/c } \\
\text { include L2 students } \\
\text { iated and used pur } \\
\text { active rather than re } \\
\text { nd priorities; } \\
\text { nowe evident in stud }\end{array}$ & $\begin{array}{l}\text { on student } \\
\text { etween } \\
\text { nowledge of and } \\
\text { teacher capacity } \\
\text { sistently centre } \\
\text { rather than } \\
\text { our improve; } \\
\text { o include explicit } \\
\text { that centre on } \\
\text { pline areas; } \\
\text { eir language } \\
\text { fully to enhance } \\
\text { literacy } \\
\text { ve regarding } \\
\text { to year. }\end{array}$ \\
\hline
\end{tabular}




\section{Conclusion}

Since this paper began with an observation from Taylor et al.'s (2005) study on literacy reform in primary schools, it seems appropriate in framing my own concluding remarks to return to one of the principal conclusions from their study. As with our SSLI research evaluation, Taylor et al. highlight the multifaceted nature of school organisational change in the development of an effective approach to literacy across the curriculum in the schools they examined, and the complex, multiyear process involved. From this, as we saw earlier, they argue that 'we must be willing to stay the course in these schools for at least five or six years in order to fully understand the nature of change' (2005: 65). This is because any substantive change '[takes] root gradually, not suddenly' (2005: 64).

And yet, there remain enormous pressures on schools - and because of the organisational constraints discussed earlier, perhaps even greater pressures on secondary schools - which militate against this long term view of change. As we know, schools will often opt into a new PD 'initiative' for 1 or 2 years, before moving on to 'something new'. Meanwhile, external educational agencies, more often than not, require an almost immediate return - for example, via demonstrable changes to student literacy outcomes in the short term - as a precondition for continued funding and/or resource support. What Taylor et al. conclude in relation to primary schools, and what the SSLI research evaluation demonstrates unequivocally in relation to secondary schools, is that neither of these approaches will effect substantive, let alone sustained, changes to teacher practices and student literacy outcomes. If we are serious about realising such changes, then we need to address two further key research questions raised by Taylor et al. (2005: 66) in their study:

(1) How can a school be encouraged or motivated to stay in a reform effort for the long haul?

(2) How can the educational research enterprise generate the resources needed to carry out long term (5-10 years) studies of school change?'

To these questions, one might add the following:

(3) How can schools and related PD initiatives combine research-attested knowledge of effective literacy theories and practices alongside knowledge of sustainable change management and leadership (and the school organisation and culture in which they both occur)?

(4) How can schools and external agencies manage to best effect the complex, reciprocal processes of external literacy facilitation and internal school change processes in literacy over time?

These complex characteristics, and their even more complex interaction, at least in relation to the SSLI study, are summarised in Figure 1.

It is hoped that the findings from the New Zealand-based SSLI research evaluation discussed here, and in the other papers in this special issue, may thus provide a useful point of reference for further work in this area. After all, there is still much that needs to be done before effective cross-curricular literacy teaching and learning becomes the norm, rather than the exception, in secondary schools. 


\section{Internal mechanisms}

\begin{tabular}{|c|c|}
\hline $\begin{array}{l}\text { Literacy } \\
\cdot \quad \text { Broad/narrow views of literacy } \\
\cdot \quad \text { Deficit/non-deficit views of literacy } \\
\cdot \quad \text { Scaffolding teaching \& learning } \\
\cdot \quad \text { Deliberate acts of teaching } \\
\cdot \quad \text { Use of appropriate literacy-related resources } \\
\cdot \quad \text { Examining data on student achievement and } \\
\text { language needs } \\
\text { Developing knowledge about language and text } \\
\text { types } \\
\text { Examining at subject level the literacy } \\
\text { requirements of texts and assessments } \\
\text { Developing students' ability to engage with } \\
\text { these texts appropriately }\end{array}$ & $\begin{array}{l}\text { Change Processes } \\
\text {. } \quad \text { School readiness } \\
\text {. Teacher readiness } \\
\text {. } \quad \text { Literacy leader \& team development } \\
\text {. } \quad \text { Cross-curricular development (breadth) } \\
\text {. Departmental development (depth) } \\
\text {. Appropriate use of facilitation } \\
\text { Understanding of role of HOD in supporting } \\
\text { literacy } \\
\text { Other initiatives/projects - integration vs. } \\
\text { competition } \\
\text { Leadership (principal/SMT; literacy leader and } \\
\text { team; HODs) } \\
\text { Modification of school structures (e.g. transition } \\
\text { points for students; timetables; staff time } \\
\text { allowances for key people; teacher release; PD } \\
\text { times) } \\
\text { Transition processes }\end{array}$ \\
\hline
\end{tabular}

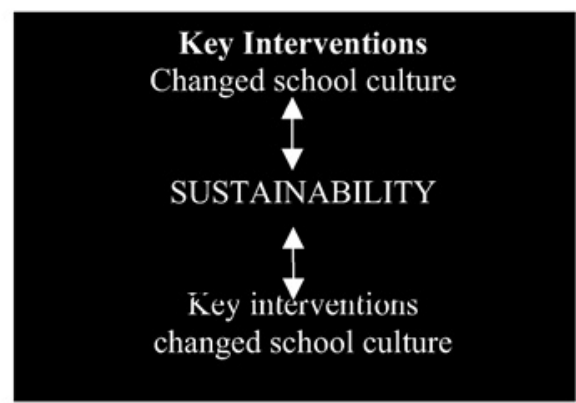

\section{Literacy}

- External Facilitators' involvement

- Extending understandings of literacy

- Strategies for establishing literacy across the curriculum

- Appropriate use of literacy resources

- School readiness - belief that all teachers are teachers of literacy and learning

- Other PD support (e.g. data collection and analysis)
Change Processes

- Development of whole school language/literacy policy (may need external facilitator to lead)

- Development of departmental language/literacy policies

- PD support for HODs/HOFs

- PD approach to support school's needs; may change over time

- An organic, rather than prescriptive PD approach

- Flexible/extended time and funding cycles

\section{External mechanisms}

Figure 1 Internal and external factors in secondary literacy across the curriculum

\section{Correspondence}

Any correspondence should be directed to Professor Stephen May, School of Education, University of Waikato, Private Bag 3105, Hamilton 3240, New Zealand (s.may@waikato.ac.nz). 


\section{Notes}

1. Guskey (2000) identified seven stages of change that teachers typically progress through in relation to PD:

- Awareness of the issues raised in PD, but with no accompanying change in action.

- Recognition of the characteristics of change, but without an understanding that the individual may need to do something new.

- Recognition of the change process and the individual's capacity to change their pedagogy.

- A focus on the teaching tasks/approaches required and their integration into classroom practice.

- Recognition of how and where new approaches can affect student learning and how they can be strategically applied to influence learning.

- Collaboration and coordination with other staff members to refine change.

- Exploration and refinement of the broader benefits of change and the overall effects on student learning.

These stages at the individual teacher level have obvious parallels with the wider, school-based phases discussed in this paper.

2. Deliberate acts of teaching result when teachers are aware of the language and thinking demands of their subjects, and deliberately use strategies which make the new language, contexts and texts accessible to students, so that they continue to develop 'appropriate background knowledge and strategies for reading a variety of texts' (Alvermann, 2002: 193).

\section{References}

Alvermann, D. (2002) Effective literacy instruction for adolescents. Journal of Literacy Research 34 (2), 189-208.

Busher, H. (2005) The project of the other: Developing inclusive learning communities in schools. Oxford Review of Education 31 (4), 459-477.

Cope, B. and Kalantzis, M. (1999) Multiliteracies: Literacy Learning and the Design of Social Futures. New York: Routledge.

Corson, D. (1999) Language Policy in Schools: A Resource for Teachers and Administrators. Mahwah, NJ: Lawrence Erlbaum.

Education Queensland (2000) Report of the Literacy Review for Queensland State Schools (pp. 10-17). Brisbane: Education Queensland.

Fink, D. (2000) Good Schools/Real Schools: Why School Reform doesn't Last. New York: Teachers College Press.

Fink, D. (2005) Leadership for Mortals: Developing and Sustaining Leaders of Learning. Thousand Oaks, CA: Corwin.

Fullan, M. (1999) Change Forces: The Sequel. Philadelphia, PA: Falmer.

Fullan, M. and Hargreaves, A. (1996) What's Worth Fighting for in Your Schools. New York: Teachers College Press.

Guskey, T. (2000) Evaluating Professional Development. Thousand Oaks, CA: Corwin.

Hargreaves, A. and Fink, D. (2006) Sustainable Leadership. San Francisco, CA: Jossey-Bass.

Hawley, W. (ed.) (2002) The Key to Effective Schools: Educational Reform as Continuous Improvement. Thousand Oaks, CA: Corwin.

Janks, H. (in press) Teaching language and power. In S. May and N. Hornberger (eds) Encyclopedia of Language and Education: Vol. 1. Language Policy and Political Issues in Education (2nd edn). New York: Springer.

Knobel, M. and Lankshear, C. (eds) (2007) A New Literacies Sampler. New York: Peter Lang.

Knott, R. (1985) The English Department in a Changing World. Milton Keynes: Open University Press.

Lankshear, C. (1997) Changing Literacies. Philadelphia, PA: Open University Press. 
Lankshear, C. and Knobel, M. (2003) New Literacies: Changing Knowledge and Classroom Learning. Philadelphia, PA: Society for Research into Higher Education and Open University Press.

May, S. (1994) Making Multicultural Education Work. Clevedon: Multilingual Matters.

May, S. (1997) School language policies. In R. Wodak and D. Corson (eds) Language Policy and Political Issues in Education. The Encyclopedia of Language and Education (Vol. 1, pp. 229-240). Dordrecht: Kluwer.

McCleskey, J. and Waldron, N. (2002) Professional development and inclusive schools: Reflections on effective practice. The Teacher Educator 37, 159-171.

Moje, E., Dillon, D. and O'Brien, D. (2000) Re-examining roles of learner, text, and context in secondary literacy. Journal of Educational Research 93, 165-180.

O'Brien, D., Stewart, R. and Moje, E. (1995) Why content literacy is difficult to infuse into the secondary school: Complexities of curriculum, pedagogy, and school culture. Reading Research Quarterly 30, 442-463.

Poulson, L. and Avramidis, E. (2003) Pathways and possibilities in professional development: Case studies of effective teachers of literacy. British Educational Research Journal $29,543-560$.

Stoll, L., Fink, D. and Earl, L. (2003) It's About Learning (and It's About Time). New York: Routledge/Falmer.

Street, B. and Hornberger, N. (eds) (in press) Encyclopedia of Language and Education: Vol 2. Literacy (2nd edn). New York: Springer.

Taylor, B., Pearson, P., Petersen, D. and Rodriguez, M. (2005) The CIERA framework: An evidence-based approach to professional development and school reading improvement. Reading Research Quarterly 40, 40-69.

Thrupp, M. and Willmott, R. (2003) Education Management in Managerialist Times: Beyond the Textual Apologists. Philadelphia, PA: Open University Press.

Wright, N. (in press) School language policies. In S. May and N. Hornberger (eds) Encyclopedia of Language and Education: Vol. 1. Language Policy and Political Issues in Education (2nd edn). New York: Springer. 